\title{
Befolkningens holdninger til genetisk epidemiologi illustrert ved spørsmål om fornyet samtykke til 61.426 personer - Helseundersøkelsen i Nord-Trøndelag (HUNT)
}

\author{
Jostein Holmen, May Britt Kjelsaas, Øystein Krüger, Hanne Ellekjær, Grete Bratberg, \\ Turid Lingaas Holmen, Kristian Midthjell, Per Arne Stavnås og Steinar Krokstad \\ HUNT forskningssenter, Institutt for samfunnsmedisin, NTNU, Verdal \\ Korrespondanse: Jostein Holmen, HUNT forskningssenter, NTNU, Neptunvegen 1, 7650 Verdal \\ Telefon: $74075180 \quad$ Telefaks: $7407581 \quad$ E-post: jostein.holmen@medisin.ntnu.no
}

\begin{abstract}
INNLEDNING
Moderne genforskning er hyppig omtalt i media og er til dels politisk kontroversielt. I den pågående debatten er det ofte vanskelig å skille mellom ulike typer genforskning. Ofte blandes f.eks. genmanipulering og kloning sammen med genetisk epidemiologisk forskning, der det brukes anonymiserte eller avidentifiserte prover, og der de statistiske analysene foregår på gruppenivå og de forskningsetiske utfordringene er langt mer beskjedne enn ved andre typer forskning. Til tross for at det i den nye biobankloven (1) er lagt svært strenge restriksjoner på denne typen forskning, er det liten kunnskap om hvilke holdninger folk har til genetisk epidemiologisk forskning. I denne artikkelen beskriver vi samtykkesituasjonen ved Helseundersøkelsen i Nord-Trøndelag 1995-97 (HUNT 2), og hvordan vi gjennomførte innhenting av fornyet samtykke hos 61.426 personer, der det i informasjonen også ble understreket at blodprøvene kunne bli brukt til genetisk forskning. Metoden, gjennomføringen og deltakelsen ved selve HUNT 2 er beskrevet i detalj tidligere (2), og vil ikke bli omtalt nærmere her.
\end{abstract}

\section{BAKGRUNN}

Under planleggingen av HUNT 2 i 1995 sendte Statens helseundersøkelser (SHUS), på vegne av HUNT styringsgruppe, søknad til Datatilsynet om konsesjon. I planene inngikk at hver deltaker skulle avgi et frivillig, informert aktivt samtykke ved å signere en samtykkeerklæring, og i søknaden ble det bl.a. lagt ved forslag til utforming av samtykkeerklæringen. Enda kort tid før HUNT 2 skulle starte i august 1995 hadde Datatilsynet imidlertid ikke ferdigbehandlet søknaden. Det var særlig punkt $5 \mathrm{i}$ den foreslåtte samtykkeerklæringen, dvs. det punktet som omhandlet lagring og bruk av blodprøven, Datatilsynet hadde motforestillinger mot. Søknadsbehandlingen endte med at Datatilsynet dikterte følgende formulering: "Jeg samtykker $i$ at blodprøven oppbevares. Ved bruk av blodprøven i for- bindelse med medisinsk forskning, vil mitt samtykke bli innhentet” (Boks 1). Hele HUNT 2-apparatet var på det tidspunktet ferdig til å sette i gang, personell var ansatt, og for at ikke hele undersøkelsen skulle utsettes, måtte styringsgruppen ta denne formuleringen inn i samtykkeerklæringen. HUNT 2 startet altså med at deltakerne signerte en formulering som betydde at blodprøven kunne lagres, men dersom den skulle brukes, uansett til hva, måtte nytt samtykke innhentes. Styringsgruppen for HUNT var ikke fornøyd med formuleringen og sendte inn klage på Datatilsynets vedtak. Etter nesten ett års behandling endret Datatilsynets sitt vedtak og godkjente den formuleringen som styringsgruppen opprinnelig hadde foreslått: "Jeg samtykker $i$ at blodprøve oppbevares. All bruk av denne vil bare skje etter godkjenning fra Datatilsynet og Regional komite for medisinsk forskningsetikk". (Boks 1). I mellomtida hadde Datatilsynet bl.a. innhentet uttalelse fra Nasjonal komite for medisinsk forskningsetikk (NEM), som i en omfattende utredning støttet styringsgruppens forslag (3). Da endringsvedtaket fra Datatilsynet forelå, hadde imidlertid ca. 33.000 personer deltatt i HUNT og signert den første versjonen av samtykket. Fra august 1996 og til HUNT var ferdig i juni 1997 ble samtykket med den nye formuleringen (versjon 2) brukt, slik at til sammen ca. 32.000 personer signerte denne versjonen.

Etter at datainnsamlingen i HUNT 2 var avsluttet hadde vi dermed en database og en biobank basert på to samtykkeformularer, og over halvparten av blodprøvene kunne ikke brukes uten at nytt samtykke ble innhentet fra deltakerne. Dette var selvsagt en svært utilfredsstillende situasjon. Vi tok derfor kontakt med REK IV for å drøfte hvordan vi kunne løse situasjonen. Det var klart at vi på ett eller annet vis måtte innhente nytt samtykke fra de ca. 33.000 personene som hadde signert den førte versjonen av samtykket. Spørsmålet var hvordan dette samtykket skulle innhentes. Videre var det i invitasjonen til HUNT 2 ikke informert spesifikt om at blodprøvene kunne brukes til genetisk forskning, da det på det tidspunktet ikke 
Boks 1. De to versjonene av samtykket (se pkt 5) som ble brukt ved Helseundersøkelsen i Nord-Trøndelag 1995-97 (HUNT 2). Versjon 2 som ble brukt fra august 1996 - juni 1997 inne i rammen. Versjon 1 som ble brukt i perioden august 1995 - juni 1996 nedenfor rammen. Tekst fra baksiden av brevet som ble sendt til HUNT-2 deltakerne i april 2002.

\section{SAMTYKKEERKLÆRINGEN I HUNT 2}

I brosjyren "Helseundersøkelsen i Nord-Trøndelag - et tilbud til deg" er jeg orientert om helseundersøkelsens formål. Jeg har fått brosjyren "hunt - spesial", som omhandler de spesialundersøkelsene jeg kan få tilbud om. Jeg er kjent med at opplysninger om meg blir behandlet strengt fortrolig og at undersøkelsen er godkjent av Datatilsynet og Regional komite for medisinsk forskningsetikk. Det er ikke satt noen spesiell tidsbegrensning for hvor lenge opplysningene kan lagres, men jeg er klar over at jeg på hvilket som helst tidspunkt kan trekke meg fra undersøkelsen og kan reservere meg mot bruk av opplysninger om meg.

1. Jeg samtykker i at resultater fra blodprøven og andre deler av undersøkelsen, samt resultater fra eventuelle spesialundersøkelser blir sendt til den legen jeg har oppgitt på spørreskjemaet.

2. Dersom jeg ikke har oppgitt navn på lege, eller legen min ikke deltar i undersøkelsen, samtykker jeg i at mine resultater sendes til kommunelege I.

3. Jeg samtykker i at jeg kan få tilbud om tilleggsundersøkelser, og i at jeg kan bli kontaktet av lege med tanke på tilbud om behandling eller for å forebygge sykdom.

4. Jeg samtykker $i$ at mine resultater kan brukes til medisinsk forskning, eventuelt ved å sammenholde opplysninger om meg med opplysninger fra andre helse- og sykdomsregistre eller mine resultater fra tidligere helseundersøkelser i Nord-Trøndelag. Når disse opplysningene sammenholdes, vil mitt navn og personnummer ikke bli tatt med.

5. Jeg samtykker i at blodprøve oppbevares. All bruk av denne vil bare skje etter godkjenning fra Datatilsynet og Regional komite for medisinsk forskningsetikk.

For de som deltok i tidsrommet fra august 1995 til juni 1996 var pkt. 5 formulert annerledes:

5. Jeg samtykker i at blodprøve oppbevares. Ved bruk av blodprøven i forbindelse med medisinsk forskning, vil mitt samtykke bli innhentet.

I samråd med bl.a. Datatilsynet ble denne formuleringen altså endret.

$V i$ spor nå om du samtykker $i$ at din blodprove oppbevares til bruk $i$ medisinsk forskning $i$ henhold til samtykkeerklaringen inne i rammen. Dersom du samtykker, behover du ikke å foreta deg noe.

Dersom du onsker å reservere deg mot at din blodprove oppbevares $i$ henhold til samtykkeerklaeringen, må du gi oss beskjed ved å sende inn slippen på dette brevet innen fristen (se motstående side av arket).

forelå noen konkrete planer om slike prosjekter. Allerede kort tid etter at HUNT 2 var ferdig kom det imidlertid spørsmål om å få bruke blodprøvene til genetiske studier. Etter en lengre, men konstruktiv dialog med REK utarbeidet vi planer for å hente inn et nytt, bekreftende samtykke, ikke bare fra de som hadde signert den første versjonen av samtykket, men fra alle deltakerne som hadde avgitt blod til biobanken. Et hovedtema i informasjonen var at blodprøvene i HUNT biobank nå også kunne brukes i genetiske studier (se boks 2). To hovedtema ble særlig diskutert med REK: Om vi denne gangen kunne bruke passivt samtykke, og innholdet i informasjonen. Vi argumenterte for at passivt samtykke var forsvarlig i denne situasjonen, bl.a. fordi deltakerne en gang tidligere hadde avgitt et aktivt samtykke. REK vurderte nøye planene for gjennomføringen og særlig den informasjonen vi skulle gi. Til slutt tilrådde REK våre planer, og vi fikk også godkjenning av Datatilsynet.

\section{Metode}

Planen hadde følgende hovedelementer:

\section{Masseutsending av brev og brosjyre}

Det ble utarbeidet et brev med en kort informasjon, hvor begge versjonene av samtykkeformularene var trykket på baksiden (boks 1). Nederst på brevarket var en svarslipp som skulle signeres dersom vedkommende ønsket å reservere seg mot at blodprøven blir brukt. Svarslippen var påtrykt strekkode som inneholdt fødselsnummer, og dessuten fødselsnummer i klartekst, men ikke navn. Det var lagt ved en ferdig frankert svarkonvolutt. Sendingen inneholdt også en brosjyre med mer utfyllende informasjon, bl.a. med HUNTs nettadresse, postadresse og telefonnummer (boks 2).

Nasjonal folkehelseinstitutt plukket ut alle HUNT 2-deltakerne som var 20 år og eldre da de hadde møtt fram til undersøkelsen, dvs. de som hadde avgitt 
Boks 2. Noen hovedpunkter i den vedlagte brosjyren "HUNT - en kilde til ny kunnskap", som ble sendt til alle HUNTdeltakerne i 2002.

- Påpeking av hvor viktig HUNT er som kunnskapskilde også i framtida, og at oppslutningen fra nord-trønderne er viktig.

- For å kunne forebygge sykdom på en mer effektiv måte, er det viktig å forstå samspillet mellom arvelige (genetiske) faktorer og miljøfaktorer.

- Eksempler på prosjekter hvor det er aktuelt å studere samspillet mellom miljøfaktorer og genetiske faktorer. Denne kunnskapen kan i neste omgang bidra til å bedre muligheten til å stille diagnoser og forebygge sykdom, bedre muligheten til å behandle sykdommer, og bedre muligheten til å skreddersy behandling til den enkelte pasient, slik at den blir mer effektiv og gir færre bivirkninger.

- Alle data som brukes i forskningen er av-identifiserte, dvs. at forskeren ikke har tilgang på navn, fødselsdato og personnummer for den enkelte. Dette innebærer at det ikke er aktuelt å gi tilbakemelding til den enkelte om nye analyseresultater fra de lagrede blodprøvene. Utenforstående, f.eks. arbeidsgivere, forsikringsselskaper o.l. får selvsagt heller ikke tilgang på resultatene.

- Kun biobankens eget personell har tilgang på blodprøvene.

- Hvis det blir aktuelt med et samarbeid med private aktører, f.eks. industri, vil dette være underlagt offentlig regulering og kontroll. I slike tilfeller kan det bli nødvendig å innhente nytt samtykke. Uansett er salg av blodprøver ikke aktuelt.

blodprøver til biobanken. De som var døde siden frammøtet ble fjernet fra navnelista kort tid før utsending.

\section{Nettsider}

Det ble laget egne nettsider på HUNTs hjemmeside med utførlige opplysninger om HUNT og tilrettelagt populærvitenskapelig informasjon om genetisk forskning generelt og genetiske epidemiologi spesielt. Bl.a. var det oppgitt lenker til andre relevante nettsider, både norske og utenlandske, der en kunne finne mer detaljert informasjon om genetisk forskning, om etikk og personvern. Ei side var spesielt tilrettelagt for at deltakerne kunne sende oss meldinger via vanlig epost eller via nettsida.

\section{Media}

Like før masseutsendingen ble det arrangert en pressekonferanse som resulterte $i$ et stort oppslag i lokalpressen, og det var i tillegg flere andre avisoppslag både før, under og etter prosjektet.

\section{Telefonberedskap}

For at det skulle være lett å kontakte oss, etablerte vi et ekstra telefonnummer og hadde eget personell som hadde telefonberedskap i fire uker etter masseutsendingen.

\section{Budskapet}

Hovedelementene i budskapet var:

- Dersom vedkommende samtykket i samtykkeerklæringen på baksiden av brevet, var det ikke nødvendig å foreta seg noe.

- Dersom en ikke samtykket, kunne en trekke samtykket ved å sende melding til HUNT forskningssenter. Meldingen kunne sendes via brev (svarslipp), telefon, faks, eller e-post. Prøven ville da bli fjernet fra biobanken og data ville bli slettet.
- Den enkelte HUNT-deltaker kan trekke tilbake samtykket når som helst også i ettertid.

- Blodprøven skal i ettertid også kunne brukes til genetisk forskning. Det ble forklart at hovedmålet med denne typen forskning er å forstå bedre hvorfor noen blir syke mens andre holder seg friske, og at vi spesielt ønsket å studere samspillet mellom arvelige faktorer og miljøfaktorer.

- All HUNT-forskning foregår ved bruk av avidentifiserte data og blodprøver, dvs. at navn og fødselsnummer blir erstattet med et tilfeldig løpenummer. Forskerne kjenner derfor ikke identiteten til de som har avgitt de enkelte prøvene eller data.

- Ingen HUNT-deltakere vil få tilbakemelding om resultater fra den genetiske analysen. Forskerne har ikke anledning til å finne fram til identiteten til den enkelte. Forskningen foregår bare på gruppenivå, og resultater for enkeltpersoner er dermed ikke interessante.

- Alle forskningsprosjekter skal også i framtida godkjennes av REK og av Datatilsynet.

- Vi er åpen for å gi all den informasjon det er behov for.

\section{Resultater}

Den 4. og 5. april 2002 ble til sammen 61.426 brev postlagt. I de påfølgende dagene kom det 43 telefonhenvendelser. Til sammen 17 av telefonene gjaldt avdøde personer. På tross av at SSBs dødefil var sjekket kort tid før utsendingen, var det likevel sendt brev til noen som var døde i mellomtida. Noen av de som ringte var dessuten opptatt av å fortelle hva som hadde hendt dem siden de hadde møtt til HUNT 2, hvilke sykdommer de hadde fått, at de hadde vært innlagt på sykehus eller begynt med nye medisiner. Det var få spørsmål om genetisk forskning og personvern, og vi 
registrerte nesten ingen kritiske motforestillinger til den informasjonen vi hadde gitt eller til den type forskning og den bruk av blodprøvene som var skissert $\mathrm{i}$ informasjonen.

I de første ukene etter utsendingen var det relativt mye oppmerksomhet om prosjektet, og vi registrerte noen misforståelser. Bl.a. var det noen som hadde oppfattet budskapet motsatt, dvs. at de måtte sende inn nytt samtykke om de fortsatt ønsket å delta. Vi besluttet derfor å sende et "kvitteringsbrev" til alle som hadde sendt inn svarslippen eller på andre måter hadde trukket samtykket. I dette brevet bekreftet vi at vi hadde mottatt melding om at de hadde trukket samtykket, og at blodprøven derfor ville bli destruert og data slettet. Dette førte til at vi fikk 45 tilbakemeldinger om at de hadde misforstått, - de hadde tvert i mot ment at vi kunne bruke blodprøven.

Etter en endelig oppsummering registrerte vi at 554 menn (1,9\%) og 633 kvinner (1,9\%), til sammen 1.187 personer $(1,9 \%)$, hadde trukket samtykket. Figur 1 viser at det var noe lavere andel reservasjoner blant de yngre enn blant de eldre. Det går dessuten fram at det blant de under 60 år var flest reservasjoner blant menn, mens det blant de over 60 år var flest kvinner.

\section{DISKUSJON}

Selv om vi var interessert i å beholde HUNTdatabasen og biobanken så intakt at den fortsatt kunne fungere som en verdifull forskningsdatabase, var det ikke noe mål å unngå at folk trakk sitt samtykke. Ved befolkningsundersøkelser som HUNT er tilliten mellom forskningsmiljøene og befolkningen helt avgjørende. Frivillig deltakelse basert på god informasjon er grunnlaget for hele databasen, og alt som kan forstyrre denne tilliten er en trussel mot denne typen forskning. Det er derfor også avgjørende at de som faktisk ikke ønsker å delta får anledning til å trekke seg.

Målet med samtykkeprosjektet var altså å informere alle HUNT 2-deltakerne på en så god måte at de kunne gjøre et reelt valg om de fortsatt ønsket at deres data og blodprøver skulle kunne brukes til forskning. Dette var selvsagt en vanskelig oppgave, både fordi budskapet var ganske komplisert, og fordi deltakerne var mange og besto av alle typer mennesker. Vi skulle forklare hva genetikk og genetisk epidemiologi var, hvorfor slik forskning er viktig, og hva som skiller denne typen genetisk forskning fra andre typer genetisk forskning. Vi skulle også forklare hvordan personvernet blir ivaretatt. Det var selvsagt en fare for at folk kunne tolke en henvendelse som dette som at nå er det noe skummelt som skal foregå.

Selv om det er bred enighet at slik forskning skal foregå på basis av et informert, aktivt, skriftlig samtykke, aksepterte både REK og Datatilsynet at det $\mathrm{i}$ denne spesielle situasjonen ble brukt passivt samtykke. Noe av bakgrunnen var forhistorien, bl.a. at versjon 1 av samtykket, som opprinnelig var diktert av Datatilsynet, ble endret etter at vi klagde.

Det andre forholdet var at alle som hadde avgitt blodprøver til biobanken en gang tidligere hadde deltatt frivillig i helseundersøkelsen, brukt tid og i den sammenhengen avgitt et aktivt samtykke om lagring og bruk av blodprøven til forskningsformål. Vi som bor i Nord-Trøndelag og arbeider ved HUNT forskningssenter i Verdal, dvs. midt i studiepopulasjonen, har mange uformelle kontakter med HUNT-deltakere $\mathrm{i}$ alle aldre. Etter vår oppfatning var det stor sannsynlighet for at de fleste mente at de allerede hadde gitt samtykke til at blodprøven kunne brukes til forsknings-

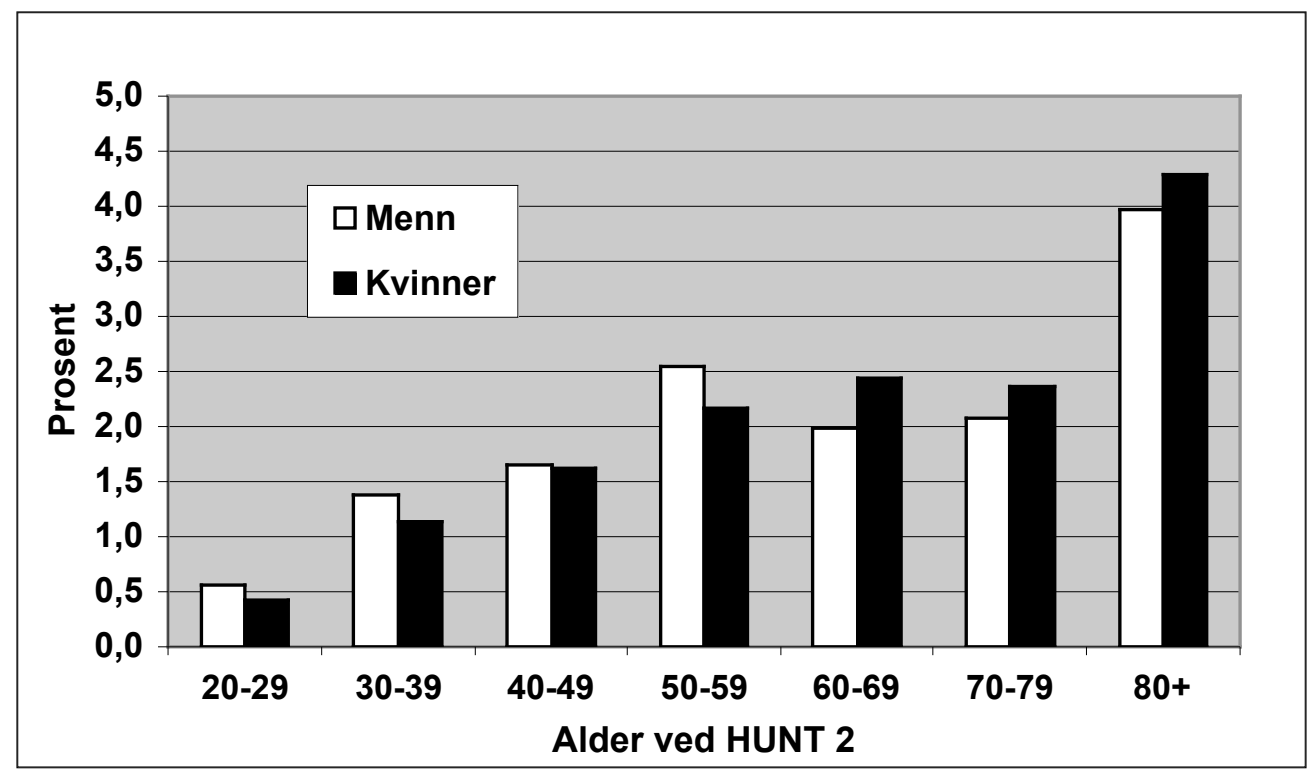

Figur 1. Resultat av spørsmål om fornyet samtykke ved HUNT 2, utsendt til 61.426 personer i april 2002. Figuren viser andel av hver aldersgruppe menn og kvinner som trakk samtykket. 554 menn og 633 kvinner, til sammen 1.187 personer $(1,9 \%)$, trakk sitt samtykke. 
formål, uansett om de hadde signert versjon 1 eller versjon 2 av samtykket. Dersom vi også skulle basert innhenting av fornyet samtykke på aktivt samtykke, altså at alle måtte signere samtykket og sende det inn, ville det være stor risiko for at mange ville oppfatte det som irrelevant og bare kaste brevet i papirkurven, ikke fordi de hadde motforestillinger mot å samtykke, men fordi de mente at de hadde gitt samtykke en gang tidligere.

Et viktig trekk ved måten samtykke-prosjektet ble gjennomført på, var at alle brevene ble sendt ut samtidig. Dersom en person som på grunn av f.eks. lesevansker eller andre grunner ikke forsto skikkelig hva det dreide seg om, var det med stor sannsynlighet flere i familien, blant naboene, vennene eller kollegene som hadde mottatt det samme brevet samtidig. HUNT og spørsmålet om nytt samtykke ble dermed et vanlig samtaleemne i tida etter at brevene var sendt ut, og de som var usikre på hva de skulle velge, kunne med stor sannsynlighet bruke familiemedlemmer eller andre kjente som referansepersoner. Bruken av massemedia var også ment å skulle sette HUNT på dagsorden for å lette slike prosesser.

De uformelle tilbakemeldingene vi fikk etter å ha sendt ut mer enn 61.000 brev bekreftet vårt inntrykk av at folk har stor tillit til måten både data og blodprøvene blir håndtert på. Det var langt færre kritiske spørsmål om hva genetisk forskning er, hva vi skulle bruke blodprøvene til, og hvordan personvernet ble ivaretatt, enn vi hadde ventet. Likevel meldte 1.187 personer eller 1,9\% fra om at de ønsket å trekke samtykket. Spørsmålet er om dette var et stort eller lite tall. Da vi gjennomførte prosjektet kjente vi ikke til noen som hadde gjort en tilsvarende undersøkelse, og hadde derfor lite å sammenlikne med. Like etter ble det imidlertid publisert en studie fra Umeå, der en hadde gitt et mindre utvalg $(\mathrm{n}=$ ca. 1.100$)$ et tilsvarende spørsmål. Det ble her brukt aktivt samtykke, slik at hver enkelt som ga sitt samtykke måtte sende inn et signert samtykke. Her var det 2,2\% som reserverte seg (4), dvs. omtrent det samme som vi fant i vår undersøkelse i Nord-Trøndelag.
De viktigste spørsmålene i ettertid er om den enkelte HUNT-deltaker forsto hva vi spurte om, om den utsendte informasjonen var så god at vedkommende ble i stand til å ta et reelt valg om hun/han ønsket å reservere seg eller ikke, og om terskelen for å sende melding om reservasjon var så lav at det faktisk ble gjort. Vi registrerte at det forekom noen misforståelser, slik at noen som ønsket å samtykke feilaktig sendte melding om at de reserverte seg. Vi la stor vekt på å informere om at det var mulig å trekke samtykket når som helst også seinere. Bl.a. på våre nettsider har vi jevnlig informert om de forskningsprosjektene som er på gang, og flere har også vært omtalt i lokalavisene uten at vi har registrert annet enn et fåtall reservasjoner $\mathrm{i}$ ettertid.

Generelt finnes det lite kunnskap om hvordan deltakere ved slike helseundersøkelser tolker den informasjonen de får og hvordan de oppfatter det samtykket de avgir. Det er derfor startet en egen studie, der grupper både av HUNT-deltakere som har samtykket, deltakere som har trukket samtykket, HUNT-forskere som har arbeidet med studien, og andre forskere er invitert til å være med på kvalitative intervjuer. Hvorfor har noen samtykket, og hvorfor har andre trukket samtykket? Hvilke positive og eventuelt negative forventninger har de til denne typen forskning? Hvordan er tilliten mellom forskere og lekfolk? Hvordan bør samtykket utformes ved framtidige helseundersøkelser av denne type (Skolbekken JA, personlig meddelelse)?

Vårt helhetsinntrykk, både fra gjennomføringen av selve HUNT 2 i perioden 1995-97 og i tida etterpå, er at HUNT-deltakerne generelt har stor tillit til HUNT og til måten data og blodprøvene blir håndtert på. Reaksjonene fra HUNT-deltakerne på det aktuelle samtykkeprosjektet gir holdepunkter for at folk flest også forstår nytten av genetisk epidemiologisk forskning, og gjerne stiller sine helsedata og blodprøver til disposisjon, forutsatt at det gis god og nøktern informasjon. Vi synes derfor det er god grunn til å spørre om dagens strenge lovgivning er $\mathrm{i}$ takt med folks holdninger og oppfatninger. Uansett er dette et felt der det er behov for langt mer forskning.

\section{REFERANSER}

1. Ot.prp. nr. 56 (2001-2002). Om lov om biobanker (biobankloven).

2. Holmen J, Midthjell K, Krüger Ø, Langhammer A, Holmen TL, Bratberg G, Vatten L, Lund-Larsen PG. The Nord-Trøndelag Health Study 1995-97 (HUNT 2): Objectives, contents, methods and participation. Norsk Epidemiologi 2003; 13 (1): 19-32.

3. Den nasjonale forskningsetiske komitè for medisin. Samtykkeerklæringer og opprettelse av personregister koblingsadgang. Uttalelse fra Den nasjonale forskningsetiske komité for medisin til Datatilsynet. NEM-NYTT, september 1996 .

4. Stegmayr B, Asplund K. Informed consent for genetic research on blood stored for more than a decade: a population based study. BMJ 2002; 325 (7365): 634-5. 